International Journal of Multidisciplinary Research AND ANALysis

ISSN(print): 2643-9840, ISSN(online): 2643-9875

Volume 04 Issue 04 April 2021

DOI: 10.47191/ijmra/v4-i4-14, Impact Factor: 6.072

Page No.- 451-454

\title{
Biological Development of Codling Moth and Biological Efficiency of Pyretroid Preparations to Control It
}

\author{
Adilbay Reyimbayevich Utepbergenov ${ }^{1}$, Nasima Genjemuratovna Shamuratova², Bakhtiyor Atajan \\ ugli Atajanov ${ }^{3}$ \\ ${ }^{1}$ Candidate of Agricultural Sciences, Associate Professor, Department of "Agrochemistry, Plant Protection and Quarantine", \\ Nukus branch of Tashkent State Agrarian University, \\ 2Doctor of Philosophy (PhD) of Agricultural Sciences, Assistant Department of "Botany and Forestry", Nukus branch of \\ Tashkent State Agrarian University, \\ ${ }^{3}$ Master degree student of the specialty "Plant Protection", $2^{\text {nd }}$ course, Nukus branch of Tashkent State Agrarian University
}

ABSTRACT: Apples are widely used by the population as a fresh and processed product at any time of the year. The relevance of the experiment is the protection of orchards from apple pests and the cultivation of high-quality products. Over the years of experiments, the main types of pests that are found in gardens and cause the greatest damage, as well as their morphological characteristics, have been studied. Laspeyresia (Carpocapsa) pomonella L. is recognized as the most harmful apple tree in our region.

KEYWORDS: apple worm development, mushroom stage, butterflies, morphological signs, degree of damage, pheromone traps, air temperature, parathyroid drugs, biological effectiveness;

\section{INTRODUCTION}

There are all the opportunities to increase the number of orchards in Uzbekistan and Karakalpakstan, especially in the natural climate, which is conducive to the cultivation of fruit trees. However, as a result of the fact that many fruit trees grow in the same place for many years, pests multiply and cause great damage to trees from roots to fruits. In recent years, a number of pests and diseases have caused serious damage to gardens. The damage caused by codling moths is especially great on the apple trees that make up the bulk of our orchards.

In their scientific works I.Aytimov and T.E.Toreniyazov [1] made special observations on the study of pest species that appear in orchards in the northern regions of the country. As a result, experiments conducted in 2014-2015 studied the main pest species that occur in orchards and cause the most damage and their morphological characteristics. Laspeyresia (Carpocapsa) pomonella L. has been identified as the most harmful codling moth in our region. Worms of the pest can penetrate the fruit and infect the seeds.

In the experiments of Sh.T Khojayev, E.Kholmuradov [4] and Sh.T Khojayev [5], the effectiveness of the method or tool used against codling moths is determined by the results obtained at the end of the season. But the biological effect on each joint of the codling moth could not be determined. As a result of the study by a creative team of scientists suggested the following method. Before each treatment of the codling moth, an insecticide-soaked belt is tied to 10 of the trees in the experimental and control (unprocessed) variants. On the 10th and 20th days after the procedure, the belts are examined to determine the difference in results

According to the information of T.Topvoldiyev, M.Rakhimov [2], if systematic control measures are not taken against codling moths, the amount of damaged fruits can reach to the following levels: $25-30 \%$ in early apple varieties, $40-50 \%$ in midsummer varieties, up to $70 \%$ and higher in late varieties.

The purpose of the experiment: to study the bio ecology of the development of the codling moth pest in the apple tree, to study the time of overwintering, egg lying and the developmental characteristics of the larvae that hatches from eggs;

Objectives of the experiment: to determine the damage caused by codling moths to apple fruit and the biological effectiveness of parathyroid preparations against them. 


\section{Biological Development of Codling Moth and Biological Efficiency of Pyretroid Preparations to Control It}

Actuality of experience and importance in production. Apples are widely used by the population as a fresh and processed product in all seasons. The actuality of the experiment is to protect orchards from apple pests and to produce high quality products.

Object and methods of research. The experiment was conducted in the apple orchard of Namuna MMTP, Amudarya district of the Republic of Karakalpakstan. The objects of research are apple orchard, codling moth pest, pheromone traps and parathyroid preparations.

In the experiment, the installation of pheromone traps and testing of parathyroid preparations was determined by the method of Sh.T.Khojaev [3].

Results of the experiment. Codling moth pheromone traps were used for proper worm control and diagnosis. At the same time, when the average spring 10 -day temperature exceeded $10^{\circ} \mathrm{C}$, one pheromone trap was installed on March 23 for one hectare of apple orchard (Picture 1).

But the butterfly was not caught during the 18-day follow-up. Then the glue and capsules in the handles were replaced. Three days later, on April 11, when the average daily temperature rose to $12.8^{\circ} \mathrm{C}, 2-3$ butterflies were found to be caught. The average number of butterflies caught in a 1-week follow-up was 18-20. Female butterflies begin to lay eggs on the leaves and buds, usually on the upper part of apple, quince and pear branches, when the air temperature is $16^{\circ} \mathrm{C}$ and above. Young worms hatching from eggs have been found to damage emerging fruits, and $70 \%$ of worms that appear later (large fruits) damage one fruit. The affected apple's worm-infested area often rots, and the worm's hole in the apple becomes hollow (Picture 2).

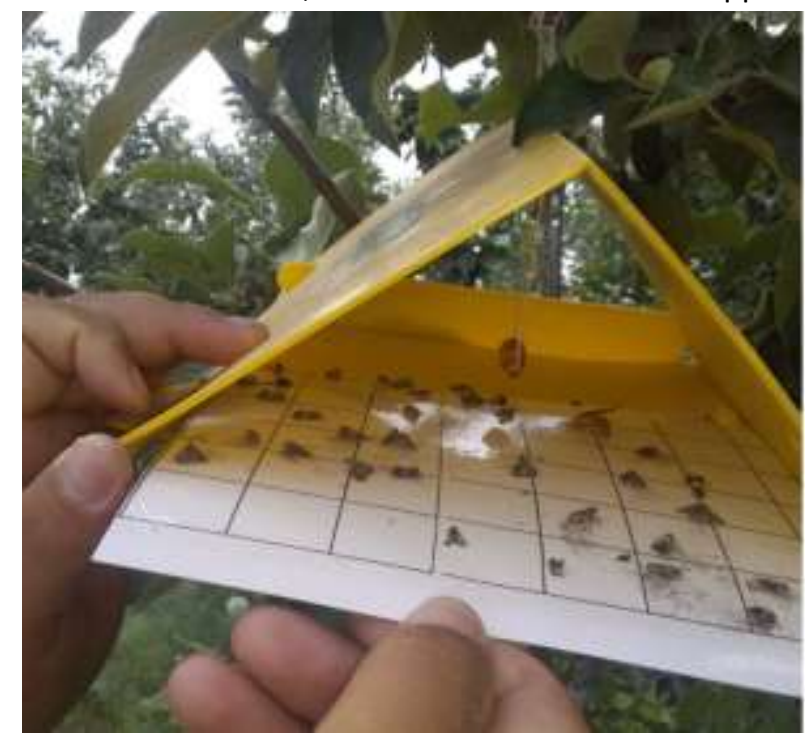

Picture 1. Codling moth which was caught by the pheromone handle.

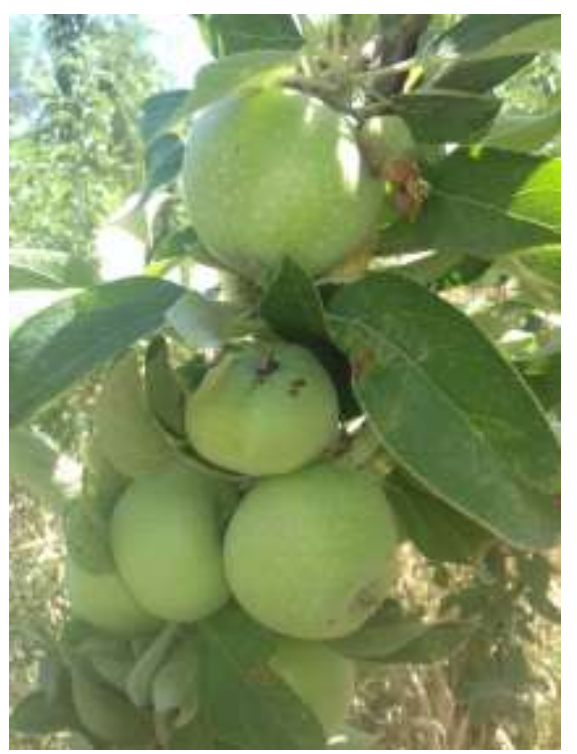

Picture 2. Apple damaged by codling moth. 


\section{Biological Development of Codling Moth and Biological Efficiency of Pyretroid Preparations to Control It}

In order to determine the biological development of the codling moth, the apple branch on which the pest butterflies lay their eggs was covered with a small entomological garden and its further development was studied (Pic. 3).

The development of the egg lasts 5-15 days, depending on the temperature, and lasts 18-40 days (on average 24 days) after moving to the fruit: during this period the worm passes 5 ages. The fruit worm turned into a pupa after 2-8 days (on average 4 days); the pupa stage lasted 8 days in July-August. This means that one joint of the pest completed its development in an average of 38 days by July.

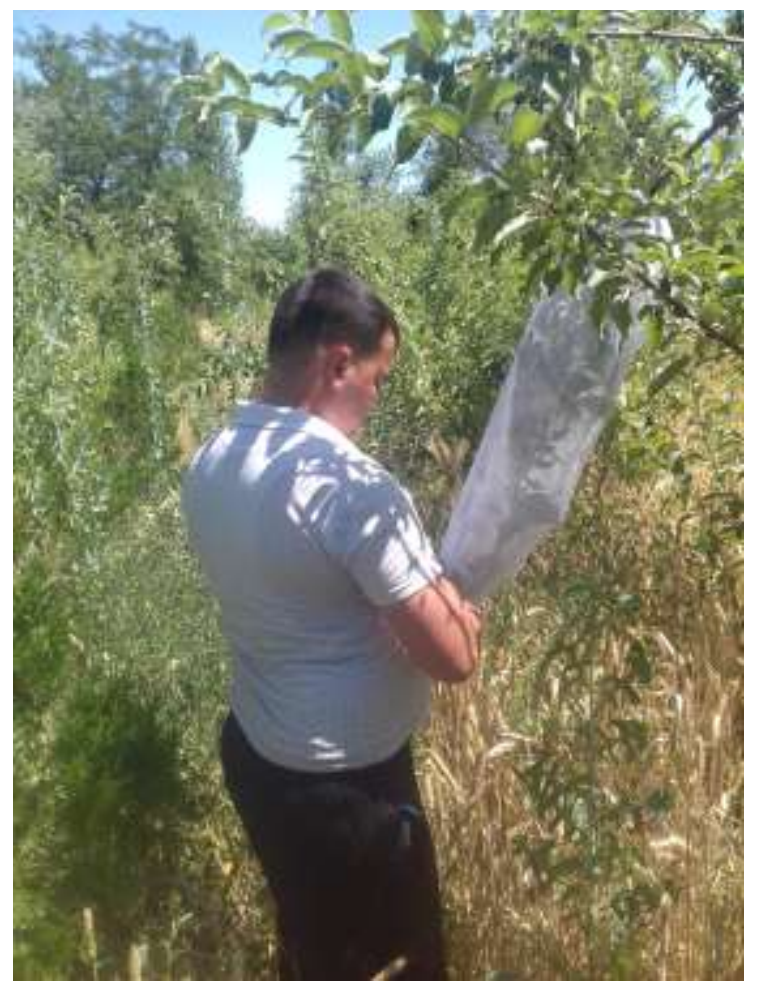

Picture 3. Use of entomological small garden to determine the biological development of the codling moth.

Due to the large number of butterflies in the handles, the apple orchards were treated with pyrethroid drugs. In this, 40\% em.k. Bi-58 (new) preparation was used in 3 different consumption rates, 1.4, 1.6 and 1.8 liters per hectare, 10\% em.k. Danitol was applied at a rate of 1.5 liters per hectare.

The experiment was performed in 5 variants, 4 repetitions. 10 apple trees were selected in each variant.

In our experiment, the number of pests was controlled at 3, 7 and 14 days before and after application of the preparation.

The biological efficiency of the variant Bi-58 was 76.9 and $79.2 \%$ when applied at the rate of 1.4 and 1.6 liters per hectare (Table 1).

Table 1. Biological efficacy of pyrethroid preparations to control codling moth

\begin{tabular}{|c|c|c|c|c|c|c|c|c|}
\hline \multirow{3}{*}{ Variants } & \multirow{3}{*}{$\begin{array}{l}\text { Using } \\
\text { preparation } \\
\text { I/ga }\end{array}$} & \multicolumn{4}{|c|}{ Average number of worms on 10 trees, piece } & \multirow{2}{*}{\multicolumn{3}{|c|}{$\begin{array}{l}\text { Biological effectiveness, in } \\
\text { days, (\%) }\end{array}$}} \\
\hline & & \multirow{2}{*}{$\begin{array}{l}\text { Before } \\
\text { spraying } \\
\text { the } \\
\text { preparation }\end{array}$} & \multicolumn{3}{|c|}{$\begin{array}{l}\text { After spraying the preparation, } \\
\text { in days }\end{array}$} & & & \\
\hline & & & 3 & 7 & 14 & 3 & 7 & 14 \\
\hline $\begin{array}{l}\text { Control } \\
\text { (unprocessed) }\end{array}$ & - & 48,5 & 51,6 & 51,52 & 54,44 & - & - & - \\
\hline $\begin{array}{l}\text { Donitol, } 10 \% \text { em.k. } \\
\text { (sample) }\end{array}$ & 1,5 & 51,0 & 14,15 & 13,0 & 11,20 & 73,9 & 76,0 & 80,4 \\
\hline Bi-58, 40\% em.k. & 1,4 & 51,3 & 14,42 & 13,42 & 13,26 & 73,6 & 75,4 & 76,9 \\
\hline Bi- $58,40 \%$ em.k. & 1,6 & 51,4 & 14,15 & 13,20 & 12,0 & 74,1 & 75,8 & 79,2 \\
\hline Bi- $58,40 \%$ em.k. & 1,8 & 54,6 & 9,6 & 7,6 & 5,2 & 83,5 & 86,9 & 91,5 \\
\hline
\end{tabular}




\section{Biological Development of Codling Moth and Biological Efficiency of Pyretroid Preparations to Control It}

Including $10 \%$ em.k. when Donitol was applied at the rate of 1.5 liters per hectare, the results for 3,7 and 14 days revealed $73.9,76.0$ and $80.4 \%$ biological efficacy, respectively. Bi-58 showed higher biological efficacy than Donitol when applied at the rate of 1.8 liters, and achieved $91.5 \%$ biological effectiveness after 14 days.

\section{CONCLUSION}

1. Spring butterflies of codling moth fly at a temperature of not less than $16^{\circ} \mathrm{C}$.

2. The development of one joint of the pest was 38 days in June and July.

3. The average number of pests on 10 trees in orchards is 48.5-54.6 pieces.

4. In the experiment, when $40 \%$ of the em.k. Bi-58 (new) preparation was applied at a rate of 1.4 and 1.6 liters per hectare, after 14 days the biological efficiency was achieved 76.9 and $79.2 \%$.

5. When using $40 \%$ em.k. Bi-58 (new) at a rate of 1.8 liters per hectare, the highest efficiency was found in our experiment, which after 14 days was $91.5 \%$.

\section{REFERENCES}

1) Aytimov I, Toreniyazov T.E. Types of pests growing on fruit trees.- NbTSAU. Materials of the scientific-practical conference "The role of scientific research in improving the profitability of agriculture: problems and ways to solve them." - Nukus: Pharma Print Nukus, 2015.- P.105-107.

2) Topvoldiyev T, Rakhimov M. Biological effectiveness of chemical preparations to control codling moth // Agrochemical protection and plant quarantine". - Tashkent, 2018.-№4.- P. 20-21.

3) Xo'jaev Sh.T. Guidelines for testing insecticides, acaricides, biologically active substances and fungicides (2nd edition) .Tashkent: KOHI-NUR LLC, 2004.-P.37-38.

4) Khodjaev Sh.T., Kholmurodov EA Fundamentals of entomology, protection of agricultural crops and agrotoxicology.Tashkent: Science and technology, 2014.- P. 283-330.

5) Xo'jaev Sh.T. Modern methods and means of combined plant protection from pests.-Tashkent: Navruz, 2015.-P.55-57. 